\title{
Omega-3 fatty acids as feed supplement modulates blood formation and body weight in Rattus norvegicus model
}

\author{
Emmanuel I. Nnamonu', Bernard O. Mgbenka², Bede I. Ezewudo ${ }^{2 *}$ (D) Edmund C. Mbegbu ${ }^{3}$, \\ Chiemekam S. Ezechukwu ${ }^{2}$ and Godwin C. Ugwu
}

\begin{abstract}
Background: Omega-3 fatty acids' inclusion as feed supplement in the diets of both human and animals has been found to play a significant role in body metabolism. The aim of this present study was to evaluate the effects of graded doses of omega-3 fatty acids on haematology and body weight of adult male and female Rattus norvegicus (Wistar albino rats) as a model animal.

Methods: A total of seventy-two adult male and female albino rats were randomly assigned into two experimental units. Each unit was grouped into three and received different treatment diets. Blood erythrocytes and weight were sampled on days 0, 14 and 28 to evaluate haematological parameters and body weight.

Results: Results showed concentration- and time-dependent significant increases $(p<0.05)$ in the packed cell volume (PCV), haemoglobin ( $\mathrm{Hb}$ ), white blood cells (WBCs), mean cell volume (MCV) and mean cell haemoglobin $(\mathrm{MCH})$ and non-significant change $(p>0.05)$ in the red blood cells (RBCs) and mean cell haemoglobin concentration $(\mathrm{MCHC})$ in male rats after day 0 . In female rats, significant increases $(p<0.05)$ were recorded in the $P C V, H b, M C V$ and MCH, whereas no significant increase was observed in the RBCs. Activities of WBCs and MCHC showed mixed trend in female rats. The results of the body weight recorded non-significant increases $(p>0.05)$ in both experimental units.

Conclusion: Our findings depict that the use of omega-3 fatty acids in the diets of both male and female rats produced a dose-dependent effect on blood formation while its role in controlling weight gain was observed. Hence, its intake in both animal and human diets should be rightly prescribed.
\end{abstract}

Keywords: Feed supplement, Body weight, Haematological parameters, Omega-3 fatty acids, Rats

\section{Background}

Omega-3 fatty acids (O3FAs) alongside omega-6 fatty acids are the two main families of polyunsaturated fatty acids. Omega-3 fatty acids are essential fatty acids that cannot be made by humans and other mammals because of the lack of internal enzymes required for desaturation of omega- 3 fatty acids but can only be derived by intake of food rich in omega-3 fatty acids (Simopoulos, 2001;

\footnotetext{
* Correspondence: ezewudobede@gmail.com

${ }^{2}$ Faculty of Biological Sciences, Department of Zoology and Environmental

Biology, University of Nigeria, Nsukka, Enugu State, Nigeria

Full list of author information is available at the end of the article
}

Kang, 2003). There are varieties of omega-3 fatty acids, but these three, alpha-linolenic acid (ALA), eicosapentaenoic acid (EPA) and docosahexanoic acid (DHA), have received much attention in scientific research. ALA is found in plant-based oils, such as in soybeans, leafy vegetables, vegetables oils, flaxseed and canola oils, and is regarded as the most ingested omega- 3 fatty acids in an average human diet worldwide (Harris, 2010; Golub et al., 2011). Eicosapentaenoic acid and docosahexanoic are sourced from microalgae, fatty fishes like mackerel and salmon as well as in fish oil supplements (Golub et al., 2011; Go et al., 2016). In addition, EPA and DHA 
can also be produced by the body through the conversion of the digested ALA (conversion taking place mostly in the liver) to eicosapentaenoic acid or docosahexanoic acid, though it has been reported that the amount produced is inadequate for body utilisation (Anderson \& Ma, 2009).

Over the past decades, there has been an overwhelming public and scientific interest in omega-3 fatty acids such as eicosapentaenoic acid (EPA) and docosahexanoic acid (DHA) toward their roles in cell structure, health promotion and body metabolism. Omega-3 fatty acids play crucial roles in the body as constituents of the phospholipid that make up the building blocks of the cell membrane (Institute of Medicine, Food and Nutrition Board, 2005). Omega-3 fatty acids are found to have chemoprotective and chemotherapeutic effects on diseases involving inflammatory and autoimmune ailments, cardiovascular disorders, cancer and type 2 diabetes (Friedman \& Moe, 2006). Additionally, omega-3 fatty acids, particularly DHA, supports vision, brain development, improve immune system, healthy heart and sperm formation (SanGiovanni \& Chew, 2005; Harris, 2010; AlAttar \& Al-Rethea, 2016). Scientific evidence revealed that DHA are high in the cell membranes of nerve cells and as such performs crucial roles in the transmission of impulses (Nagy \& Tiuca, 2017). Omega-3 fatty acids in the form of EPA can synthesise signalling molecules, eicosanoids that have anti-inflammatory roles, enhance vasodilation and alter platelet aggregation. These actions, especially the anti-inflammatory roles of omega- 3 fatty acids including its function in modulating body lipid accumulation, are crucial in the chemoprotective roles they exhibit in cardiovascular disorder (Golub et al., 2011).

Investigations conducted to ascertain the status of fat intakes by humans have recorded a downward-spiral worldwide over two decades ago (Troiano, Briefel, Carroll, \& Bialostosky, 2000; Swan, 2004), but the intake of polyunsaturated O3FAs increased positively, synergistically with an overwhelming elevation in overweight and obesity cases (Ailhaud et al. 2006). Morbidity and mortality linked to obesity have continued to increase worldwide despite reduction in intakes of high fats which favour accumulation of excess body fats. Conversely, there has been corresponding increase in physical inactivity and high intakes of "junk foods" that are low in dietary fibre but rich in calories, contributing to the rise in obesity (W.H.O. 2016). Aerobic exercise and proper dieting have been recommended by most public health bodies as the remedy for tackling excess weight gain. However, many obese patients find it difficult to adjust to these lifestyles as time progresses. Since obesity has been considered an inflammatory disorder, inclusion of dietary supplements with anti-inflammatory roles in the diets of people facing overweight is seen as a promising approach to tackling overweight (de Mello et al. 2018). Some research studies have confirmed that incorporating long chain polyunsaturated omega- 3 fatty acids in the diet regime of overweight individuals/animals resulted to a reduced adiposity and an increase in lean tissue growth on a calorie-for-calorie basis (Krebs et al. 2006; Thorsdottir et al. 2007; Hassanali et al. 2010), while a negative effect was derived with the use of omega-6 fatty acids (Birch et al. 2002; Nuernberg et al. 2011). It was discovered that diets rich in omega- 6 fatty acids elicit the omega- 6 fatty acid precursor, eicosanoids, which supports the production of prostaglandin E2, thromboxane A2 and leukotriene B4 (synthesised from arachidonic acid; ARA), which are inducers of vasoconstriction, platelet aggregation and inflammation, which is the origin of obesity (Simopoulos, 2001; Gabbs et al. 2015). On the other hand, high intake of omega-3 fatty acids that are rich in EPA and DHA and less ARA tends to mitigate the intensity of pro-inflammatory eicosanoids production, thereby preventing inflammation (MartínezFernández et al. 2015).

Often times, the wrong intake of drugs as well as other food supplements in boosting immune system or treating a particular ailment can cause blood abnormalities and other alterations in the body systems of an organism. Harmful effects of foreign compounds especially drugs in the form of feed supplement on animals' blood constituents are determined through careful assessment of the various blood parameters (Ashafa, Yakubu, Grierson, \& Afolayan, 2009). Alterations in blood parameters have been used to elucidate the impact of supplements in diets of organisms (Majid, Mohsen, Abas, \& Sayed, 2010). Due to the paucity of scientific literature on the effects of omega-3 fatty acids (O3FAs) that are dose-dependent on the haematology and body weight considering the nutritional importance of O3FAs and its anti-inflammatory properties, it becomes needful that this study be conducted to elucidate the effects of graded doses of O3FAs as feed supplement on haematology and body weight using Rattus norvegicus (Wistar albino rats) as a model animal.

\section{Material and methods \\ Drug used}

Ultra-pure O3FAs (91\% pure omega-3 content) was purchased from Prevention Pharmaceuticals, Lambertville, Michigan, USA.

\section{Animal procurement and care}

Adult male and female albino rats (with no history of prior use in any investigation) were obtained from the Genetics and Experimental Animal Breeding Laboratory of the Department of Zoology and Environmental Biology, University of Nigeria, Nsukka, Nigeria. The animals were hygienically housed in stainless wire rat cages and 
acclimatised for 2 weeks. The ethical conditions and experimental protocol governing the use and conduct of experiments with live animals were strictly observed as approved by the University of Nigeria, Nsukka, Senate Committee on Medical and Research Ethics (2013) (The University of Nigeria, Nsukka, 2013).

\section{Experimental design}

Seventy-two adult male rats weighing 142.26-171.96 g and female albino rats weighing 153.86-165.18 g (thirtysix males and thirty-six females) were used for the study. The male rats were alone in a separate experimental unit (separate apartment and cages), while the females were also alone in another experimental unit (separate apartment and cages). The first unit consists of thirty-six male rats randomly assigned into three groups of twelve rats each. Each group was randomly replicated three times (four rats per replicate). Group I served as the control. They received commercial growers chick mash (18\% crude protein) and $0.3 \mathrm{mlv} / \mathrm{v}$ tween 80 (placebo). Group II was fed commercial growers chick mash $(18 \%$ crude protein) and $150 \mathrm{mg} / \mathrm{kg}$ O3FAs while group III was fed commercial growers chick mash $(18 \%$ crude protein) and $250 \mathrm{mg} / \mathrm{kg}$ O3FAs. The second experimental unit also consists of thirty-six female rats, grouped, replicated and treated same as in the first unit.

\section{Blood collection}

Blood was collected on the day 0 prior to the commencement of the trial. Thereafter, blood was collected on the 14 and 28 days of the trial period. The method described by Hoff (2010) was followed during blood collection. On each sampling day, two rats were randomly selected from each replicate and anaesthesia using diethyl ether. Blood samples $(5 \mathrm{ml})$ were collected via orbital venous plexus with non-heparinised syringe and later transferred into EDTA tubes for haematological assay.

\section{Analyses of haematological profile}

The method of Sood (2006) was followed for haemoglobin $(\mathrm{Hb})$ content and total red blood cells (RBCs) count. The method of Ochei and Kolhatkar (2007) was followed in estimating packed cell volume (PCV) and white blood cells (WBCs) count.

Erythrocyte indices like mean cell volume (MCV), mean cell haemoglobin $(\mathrm{MCH})$ and the mean cell haemoglobin concentration $(\mathrm{MCHC})$ calculations followed Baker, Silverton, \& Pallister (2001) and derived from the results of $\mathrm{Hb}, \mathrm{RBCs}$ count, PCV and WBCs count as shown below:

$$
\operatorname{MCV}(\mathrm{fl} / \text { cell })=\frac{P C V(\%) \times 10}{\mathrm{RBC} \text { count in millions } / \mathrm{mm} 3}
$$

$$
\begin{aligned}
& \mathrm{MCH}(\mathrm{pg})=\frac{H b\left(\frac{g}{d l}\right) \times 10}{\mathrm{RBC} \text { count in millions } / \mathrm{mm}} \\
& \mathrm{MCHC}(\mathrm{g} / \mathrm{dl})=\frac{H b\left(\frac{g}{d l}\right) \times 100}{P C V(\%)}
\end{aligned}
$$

\section{Measurement of body weights}

Mettler electronic balance PC 2000 was used in measuring each rat's body weight at days 0,14 and 28 .

\section{Statistical analysis}

Data analysis was carried out with Statistical Package for Social Sciences (SPSS), version 20.0 for Windows, and one-way analysis of variance (ANOVA). The means were separated using Duncan's new multiple range test while differences in the means were considered significant at probability values less than $5 \%(p<0.05)$. The results were presented as the mean \pm standard error of the mean (SEM).

\section{Results}

Effects of graded doses of O3FA on haematological parameters of male albino rats

Table 1 shows the effects of graded doses (150 and 250 $\mathrm{mg} / \mathrm{kg}$ ) of omega-3 fatty acids (O3FAs) on packed cell volume (PCV), red blood cells (RBCs), haemoglobin $(\mathrm{Hb})$, white blood cells (WBCs), mean cell volume $(\mathrm{MCV})$, mean cell haemoglobin $(\mathrm{MCH})$ and mean cell haemoglobin concentration $(\mathrm{MCHC})$ of male albino rats. The results showed concentration- and time-dependent significant increases $(p<0.05)$ in the packed cell volume $(\mathrm{PCV})$, haemoglobin $(\mathrm{Hb})$, white blood cells (WBCs), mean cell volume (MCV) and mean cell haemoglobin $(\mathrm{MCH})$ and non-significant change $(p>0.05)$ in the red blood cells (RBCs) and mean cell haemoglobin concentration $(\mathrm{MCHC})$ in male rats after day 0 . In addition, it was observed that male rats that received $250 \mathrm{mg} / \mathrm{kg}$ graded doses of omega-3 fatty acids (O3FAs) had improved haematological indices after day 14 but those fed with $150 \mathrm{mg} / \mathrm{kg}$ graded doses of O3FAs performed better at day 14 .

\section{Effects of graded doses of O3FA on haematological parameters of female albino rats}

Table 2 shows the effects of graded doses (150 and 250 $\mathrm{mg} / \mathrm{kg}$ ) of O3FAs on PCV, RBCs, Hb, WBCs, MCV, $\mathrm{MCH}$ and $\mathrm{MCHC}$ of female albino rats. Our findings recorded concentration- and time-dependent significant increases $(p<0.05)$ in the $\mathrm{PCV}, \mathrm{Hb}, \mathrm{MCV}$ and $\mathrm{MCH}$, whereas non-significant increase was observed in the RBCs when compared with the baseline (day 0). 
Table 1 Effects of O3FAs on haematological indices in male rats

\begin{tabular}{|c|c|c|c|c|}
\hline \multirow[b]{2}{*}{ Parameter } & \multirow[b]{2}{*}{ Groups } & \multicolumn{3}{|l|}{ Duration (day) } \\
\hline & & 0 & 14 & 28 \\
\hline \multirow[t]{3}{*}{$\overline{P C V}(\%)$} & Control & $38.40 \pm 0.5^{\mathrm{a} 1}$ & $40.20 \pm 0.37^{\mathrm{a} 2}$ & $46.00 \pm 0.84^{\mathrm{a} 3}$ \\
\hline & $150 \mathrm{mgkg}^{-1}$ O3FA & $41.20 \pm 0.37^{\mathrm{b} 1}$ & $43.60 \pm 0.68^{\mathrm{b} 2}$ & $51.40 \pm 0.75^{\mathrm{b} 3}$ \\
\hline & $250 \mathrm{mgkg}^{-1}$ O3FA & $40.80 \pm 0.37^{\mathrm{b} 1}$ & $42.80 \pm 0.49^{\mathrm{b} 2}$ & $51.60 \pm 0.68^{\mathrm{b} 3}$ \\
\hline \multirow[t]{3}{*}{$\mathrm{RBC}\left(\times 10^{6} \mathrm{cells} / \mu \mathrm{l}\right)$} & Control & $7.30 \pm 0.07^{\mathrm{a} 1}$ & $7.32 \pm 0.07^{\mathrm{a} 1}$ & $7.32 \pm 0.07^{\mathrm{a} 1}$ \\
\hline & $150 \mathrm{mgkg}^{-1}$ O3FA & $7.24 \pm 0.08^{\mathrm{a} 1}$ & $7.27 \pm 0.07^{\mathrm{a} 1}$ & $7.29 \pm 0.05^{\mathrm{a} 1}$ \\
\hline & $250 \mathrm{mgkg}^{-1}$ O3FA & $7.26 \pm 0.05^{\mathrm{a} 1}$ & $7.27 \pm 0.05^{\mathrm{a} 1}$ & $7.27 \pm 0.042^{\mathrm{a} 1}$ \\
\hline \multirow[t]{3}{*}{$\mathrm{Hb}(\mathrm{g} / \mathrm{dl})$} & Control & $12.80 \pm 0.81^{\mathrm{a} 1}$ & $13.39 \pm 0.13^{\mathrm{a} 2}$ & $15.33 \pm 0.28^{\mathrm{a} 3}$ \\
\hline & $150 \mathrm{mgkg}^{-1}$ O3FA & $13.73 \pm 0.13^{\mathrm{b} 1}$ & $14.53 \pm 0.23^{\mathrm{b} 2}$ & $17.13 \pm 0.25^{\mathrm{b} 3}$ \\
\hline & $250 \mathrm{mgkg}^{-1}$ O3FA & $13.60 \pm 0.13^{b 1}$ & $14.27 \pm 0.16^{\mathrm{b} 2}$ & $17.20 \pm 0.23^{\mathrm{b} 3}$ \\
\hline \multirow[t]{3}{*}{$\operatorname{WBC}\left(\times 10^{3} / \mu \mathrm{l}\right)$} & Control & $8.92 \pm 0.02^{\mathrm{a} 1}$ & $9.00 \pm 0.03^{\mathrm{a} 2}$ & $9.03 \pm 0.04^{\mathrm{a} 2}$ \\
\hline & $150 \mathrm{mgkg}^{-1}$ O3FA & $8.97 \pm 0.02^{\mathrm{a} 1}$ & $9.00 \pm 0.01^{\mathrm{a} 2}$ & $9.03 \pm 0.02^{\mathrm{a} 2}$ \\
\hline & $250 \mathrm{mgkg}^{-1}$ O3FA & $8.96 \pm 0.03^{\mathrm{a} 1}$ & $9.01 \pm 0.02^{\mathrm{a} 2}$ & $9.05 \pm 0.03^{\mathrm{a} 2}$ \\
\hline \multirow[t]{3}{*}{ MCV (fl) } & Control & $52.61 \pm 0.42^{\mathrm{a} 1}$ & $55.10 \pm 0.98^{\mathrm{a} 2}$ & $63.00 \pm 0.70^{\mathrm{a} 3}$ \\
\hline & $150 \mathrm{mgkg}^{-1}$ O3FA & $56.63 \pm 0.94^{b_{1}}$ & $59.76 \pm 1.28^{\mathrm{b} 1}$ & $70.25 \pm 1.35^{\mathrm{b} 2}$ \\
\hline & $250 \mathrm{mgkg}^{-1}$ O3FA & $56.05 \pm 0.46^{\mathrm{b} 1}$ & $58.80 \pm 0.80^{\mathrm{b} 2}$ & $70.88 \pm 0.94^{\mathrm{b} 3}$ \\
\hline \multirow[t]{3}{*}{ MCH (pg) } & Control & $17.54 \pm 0.14^{\mathrm{a} 1}$ & $18.17 \pm 0.33^{\mathrm{a} 1}$ & $20.94 \pm 0.24^{\mathrm{a} 2}$ \\
\hline & $150 \mathrm{mgkg}^{-1}$ O3FA & $18.88 \pm 0.32^{\mathrm{b} 1}$ & $19.92 \pm 0.42^{\mathrm{b} 1}$ & $23.42 \pm 0.45^{\mathrm{b} 1}$ \\
\hline & $250 \mathrm{mgkg}^{-1}$ O3FA & $18.72 \pm 0.14^{\mathrm{b} 1}$ & $19.62 \pm 0.26^{\mathrm{b} 2}$ & $23.65 \pm 0.30^{\mathrm{b} 3}$ \\
\hline \multirow[t]{3}{*}{$\mathrm{MCHC}(\mathrm{g} / \mathrm{dl})$} & Control & $33.34 \pm 0.00^{\mathrm{a} 1}$ & $33.30 \pm 0.02^{\mathrm{a} 1}$ & $33.33 \pm 0.00^{\mathrm{a} 1}$ \\
\hline & $150 \mathrm{mgkg}^{-1}$ O3FA & $33.33 \pm 0.00^{\mathrm{a} 1}$ & $33.33 \pm 0.00^{\mathrm{a} 1}$ & $33.33 \pm 0.00^{\mathrm{a} 1}$ \\
\hline & $250 \mathrm{mgkg}^{-1}$ O3FA & $33.34 \pm 0.00^{\mathrm{a} 1}$ & $33.30 \pm 0.02^{\mathrm{a} 1}$ & $33.33 \pm 0.00^{\mathrm{a} 1}$ \\
\hline
\end{tabular}

Values with different alphabet superscript in a column were significantly $(p<0.05)$ different

Activities of WBCs and MCHC showed contrasting concentration- and time- dependent significant changes after day 0 when compared with the control. Furthermore, we discovered that female rats that received $150 \mathrm{mg} / \mathrm{kg}$ graded doses of omega- 3 fatty acids (O3FAs) had improved haematological indices throughout the trial period than those fed with $250 \mathrm{mg} / \mathrm{kg}$ graded doses of O3FAs.

\section{Effects of graded doses of O3FA on body weight $(\mathrm{g})$ of male and female albino rats}

Figures 1 and 2 show the effects of graded doses (150 and $250 \mathrm{mg} / \mathrm{kg}$ ) of omega-3 fatty acids (O3FAs) and control on body weight of male and female albino rats. From our observations on the body weights of the treated rats (male and female rats), the results showed concentration- and time- dependent non-significant increases $(p>0.05)$ in both the experimental units after day 0 and when compared against the control.

\section{Discussion}

\section{Effects of omega-3 fatty acids on some haematological parameters}

Systemic effects of foreign compounds such as drugs on animals can be properly determined through a comprehensive haematology test (Ashafa, Yakubu, Grierson, \& Afolayan, 2009; Ukwuani, Abubakar, Hassan, \& Agaie, 2012), since blood performs crucial physiological roles on the general body metabolism. Red blood cell (erythrocyte) is one of the blood corpuscles that transports oxygen from the lungs or gills to all body tissues then carry carbon dioxide to the lungs for proper excretion. From our findings, omega-3 fatty acids (O3FAs) caused non-significant increase $(p>0.05)$ in the red blood cells in both male and female rats. This could suggest that administration of omega- 3 fatty acids as feed supplement does not play a significant role in red blood cells formation. This finding is at variance with Ndem, Akpanabiatu, \& Essien (2008) and Al-Daraji et al. (2010) however agrees with the finding of Kooshki, Taleban, Tabibi, \& Hedayati (2011). In addition, Vernaglione, Cristofano \& Chimienti (2008) observed no significant effect on the number of RBCs when $2 \mathrm{~g}$ omega3 fatty acids supplement was administered daily to haemodialysis patients, for four (4) months. Surprisingly, there was a significant increase $(p<0.05)$ in the packed cell volume (PCV) and haemoglobin $(\mathrm{Hb})$ in both rats administered with different concentrations of omega-3 fatty acids. This suggests that the administration of 
Table 2 Effect of O3FAs on haematological indices in female rats

\begin{tabular}{|c|c|c|c|c|}
\hline \multirow[b]{2}{*}{ Parameter } & \multirow[b]{2}{*}{ Groups } & \multicolumn{2}{|l|}{ Duration (day) } & \multirow[b]{2}{*}{28} \\
\hline & & 0 & 14 & \\
\hline \multirow[t]{3}{*}{ PCV (\%) } & Control & $39.40 \pm 0.51^{b 1}$ & $41.40 \pm 0.51^{b 2}$ & $42.80 \pm 0.37^{\mathrm{ab} 2}$ \\
\hline & $150 \mathrm{mgkg}^{-1}$ O3FA & $37.00 \pm 0.45^{\mathrm{a} 1}$ & $39.20 \pm 0.37^{\mathrm{a} 2}$ & $42.20 \pm 0.74^{\mathrm{ab} 3}$ \\
\hline & $250 \mathrm{mgkg}^{-1}$ O3FA & $35.80 \pm 0.37^{\mathrm{a} 1}$ & $38.20 \pm 0.37^{\mathrm{a} 2}$ & $40.80 \pm 0.37^{\mathrm{a} 3}$ \\
\hline \multirow[t]{3}{*}{ RBC $\left(\times 10^{6}\right.$ cells $\left./ \mu l\right)$} & Control & $7.36 \pm 0.07^{\mathrm{a} 1}$ & $7.38 \pm 0.07^{\mathrm{a} 1}$ & $7.39 \pm 0.07^{\mathrm{a} 1}$ \\
\hline & $150 \mathrm{mgkg}^{-1}$ O3FA & $7.27 \pm 0.06^{\mathrm{a} 1}$ & $7.30 \pm 0.06^{\mathrm{a} 1}$ & $7.29 \pm 0.06^{\mathrm{a} 1}$ \\
\hline & $250 \mathrm{mgkg}^{-1}$ O3FA & $7.36 \pm 0.05^{\mathrm{a} 1}$ & $7.37 \pm 0.05^{\mathrm{a} 1}$ & $7.37 \pm 0.04^{\mathrm{a} 1}$ \\
\hline \multirow[t]{3}{*}{$\mathrm{Hb}(\mathrm{g} / \mathrm{dl})$} & Control & $13.13 \pm 0.17^{\mathrm{b} 1}$ & $13.80 \pm 0.17^{\mathrm{b} 12}$ & $13.94 \pm 0.29^{\mathrm{a} 2}$ \\
\hline & $150 \mathrm{mgkg}^{-1}$ O3FA & $12.47 \pm 0.25^{\mathrm{a} 1}$ & $13.07 \pm 0.12^{\mathrm{a} 1}$ & $14.73 \pm 0.24^{\mathrm{a} 2}$ \\
\hline & $250 \mathrm{mgkg}^{-1}$ O3FA & $11.93 \pm 0.12^{\mathrm{a} 1}$ & $12.73 \pm 0.13^{\mathrm{a} 2}$ & $14.07 \pm 0.29^{\mathrm{a} 3}$ \\
\hline \multirow[t]{3}{*}{ WBC $\left(\times 10^{3} / \mu l\right)$} & Control & $8.90 . \pm 0.02^{\mathrm{a} 1}$ & $9.00 \pm 0.03^{\mathrm{a} 1}$ & $9.05 \pm 0.04^{\mathrm{a} 1}$ \\
\hline & $150 \mathrm{mgkg}^{-1}$ O3FA & $8.99 \pm 0.01^{\mathrm{a} 1}$ & $9.00 \pm 0.02^{\mathrm{ab} 1}$ & $9.04 \pm 0.02^{\mathrm{a} 1}$ \\
\hline & $250 \mathrm{mgkg}^{-1}$ O3FA & $8.96 \pm 0.02^{\mathrm{a} 1}$ & $9.06 \pm 0.01^{b 2}$ & $9.05 \pm 0.03^{\mathrm{a} 2}$ \\
\hline \multirow[t]{3}{*}{$\mathrm{MCV}(\mathrm{fl})$} & Control & $53.52 \pm 0.47^{\mathrm{a} 1}$ & $56.08 \pm 0.44^{c 2}$ & $57.90 \pm 0.37^{a 3}$ \\
\hline & $150 \mathrm{mgkg}^{-1}$ O3FA & $51.18 \pm 0.52^{\mathrm{b} 1}$ & $53.74 \pm 0.29^{\mathrm{b} 2}$ & $57.90 \pm 0.91^{\mathrm{b3}}$ \\
\hline & $250 \mathrm{mgkg}^{-1}$ O3FA & $48.63 \pm 0.72^{\mathrm{a} 1}$ & $51.82 \pm 0.69^{\mathrm{a} 2}$ & $55.35 \pm 0.74^{\mathrm{b} 3}$ \\
\hline \multirow[t]{3}{*}{$\mathrm{MCH}(\mathrm{pg})$} & Control & $17.84 \pm 0.15^{c 1}$ & $18.51 \pm 0.18^{\mathrm{a} 2}$ & $18.84 \pm 0.26^{\mathrm{a} 2}$ \\
\hline & $150 \mathrm{mgkg}^{-1}$ O3FA & $17.15 \pm 0.25^{\mathrm{b} 1}$ & $17.91 \pm 0.95^{\mathrm{b} 2}$ & $20.21 \pm 0.31^{c 3}$ \\
\hline & $250 \mathrm{mgkg}^{-1}$ O3FA & $16.21 \pm 0.24^{\mathrm{a} 1}$ & $17.27 \pm 0.23^{\mathrm{a} 2}$ & $19.09 \pm 0.47^{\mathrm{b3}}$ \\
\hline \multirow[t]{3}{*}{$\mathrm{MCHC}(\mathrm{g} / \mathrm{dl})$} & Control & $33.33 \pm 0.07^{\mathrm{a} 1}$ & $33.33 \pm 0.37^{\mathrm{a} 1}$ & $32.55 \pm 0.43^{\mathrm{a} 1}$ \\
\hline & $150 \mathrm{mgkg}^{-1}$ O3FA & $33.68 \pm 0.35^{\mathrm{a} 1}$ & $33.32 \pm 0.29^{\mathrm{a} 1}$ & $34.91 \pm 0.03^{\mathrm{b} 2}$ \\
\hline & $250 \mathrm{mgkg}^{-1}$ O3FA & $33.33 \pm 0.19^{\mathrm{a} 1}$ & $33.33 \pm 0.46^{\mathrm{a} 1}$ & $34.47 \pm 0.54^{\mathrm{b} 2}$ \\
\hline
\end{tabular}

Values with different alphabet superscript in a column were significantly $(p<0.05)$ different

omega-3 fatty acids did not alter the process of erythropoiesis as the activities of PCV and $\mathrm{Hb}$ were increased (Archibong et al., 2014). Also, the significant increase in $\mathrm{Hb}$ in all the treatments indicates that the oxygencarrying capacity of the rat blood was not limited. Red blood cell indices (MCV, MCH and $\mathrm{MCHC}$ ) specifically provide useful information in diagnoses of the cause and severity of anaemia (Archibong et al., 2014). We observed increased $\mathrm{MCV}$ and $\mathrm{MCH}$ in both treated rats fed varying doses of omega-3 fatty acids while in male rats, the MCHC activities was non-significant $(p>0.05)$ but produced a mixed trend in the female rats at different doses of omega- 3 fatty acids. From the result, we can infer that the introduction of omega-3 fatty acids

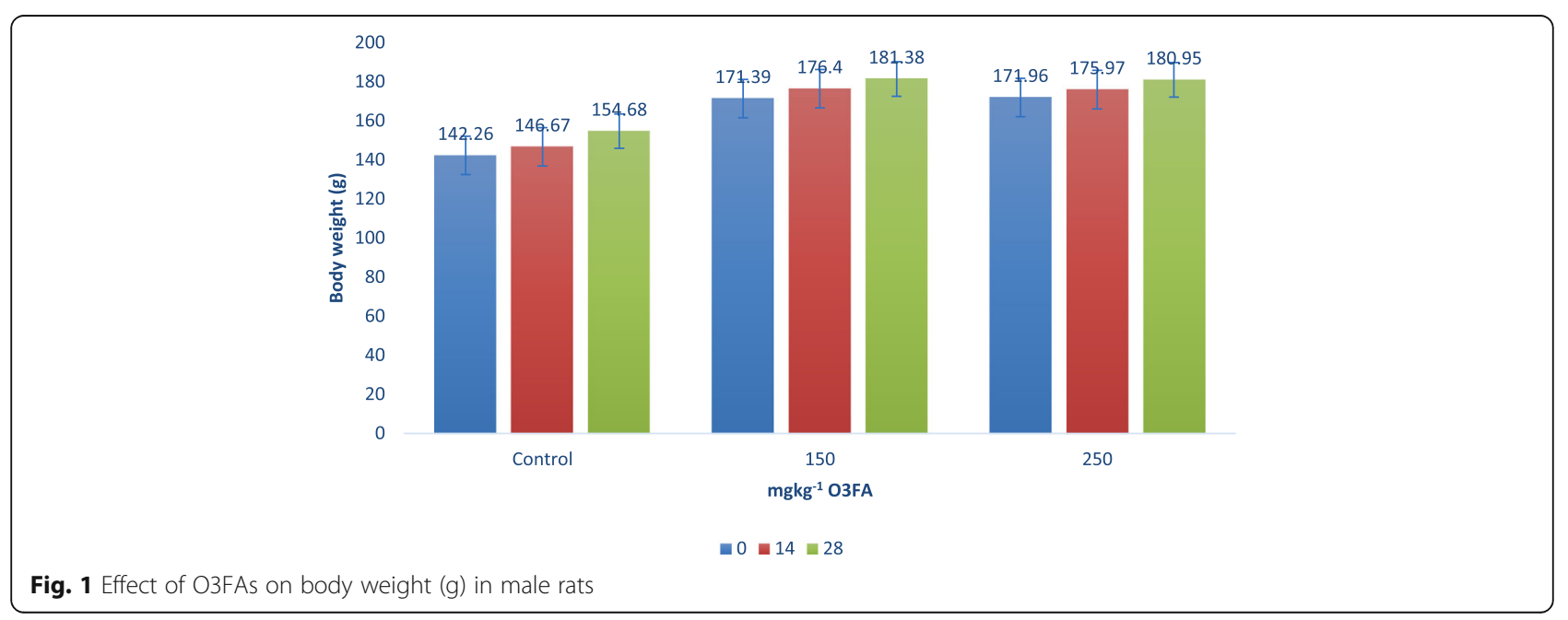




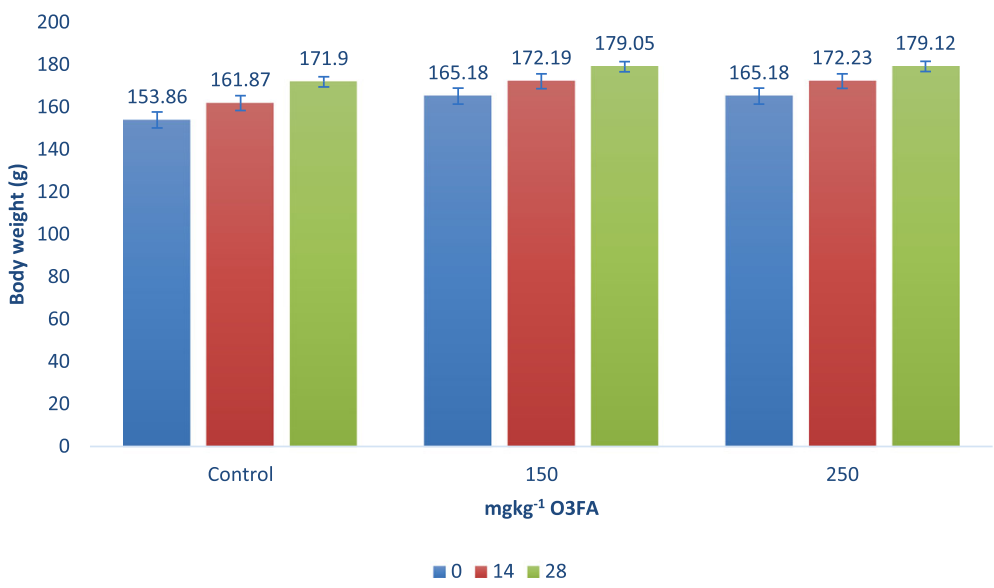

Fig. 2 Effect of O3FAs on body weight (g) in female rats

did not induce anaemic condition in the rats. The increased MCV shows that the introduction of omega-3 fatty acids did not cause erythrocytes shrinkage. The shrinking of erythrocytes occurs as a result of stress, anaemic condition or as a result of poor erythropoiesis due to introduction of harmful substance(s) on the haemopoietic tissues (Nwani et al., 2013). Omega-3 fatty acids caused a significant increase $(p<0.05)$ in white blood cell (WBC) count after day 0 but recorded a nonsignificant change at days 14 and 28 in male rats fed different concentrations of omega- 3 fatty acids. The finding in female rats showed mixed trend in white blood cells at different sampling day with increased WBCs count recorded at day 14 while a slight drop was recorded at day 28. These results depict that initial intake of omega-3 fatty acids can boost lymphocyte (Eno, Owo, Itam, \& Konya, 2001), but its continuous usage or high intake over time can have an inhibitory effect on the role of immune system (Kelley, 2001). Kelly (2001) reported that continuous or increased intake of O3FA results in inhibition of lymphocytes proliferation by decreasing neutrophil chemotaxis, natural killer cell (NK-cell) response and the production of proinflammatory cytokines like interleukin (IL-1 $\beta$ ) and tumour necrosis factor $\alpha$ (TNF$\alpha)$ and proinflammatory eicosanoids- prostaglandin E2 (PGE2) and leukotriene B4 (LTB4). This inhibitory effect of omega- 3 fatty acids has led to its inclusion in the diets of patients suffering from severe inflammatory and autoimmune ailments (Kelley, 2001; Varney, Hardman, \& Sollars, 2009). In contrast, the study of Yaqoob et al. (2000) observed no inhibition of white blood cell (lymphocytes) proliferation even at higher inclusion levels of the omega-3 fatty acids. The absence of inhibition in their study could be due to addition of vitamin $\mathrm{E}$ in their diet, which has the ability to reverse the inhibition of lymphocyte proliferation initiated by O3FA supplementation.
We, therefore suggest that the ability of O3FAs to influence the various blood parameters tested significantly could be as a result of its positive influence on haematopoiesis. This report is supported by the findings of Varney, Hardman, \& Sollars (2009) who concluded that the use of O3FAs modulates haematopoiesis by restoring a rapidly differentiate myeloid progenitor cells compartment in the bone marrow to a healthy progenitor cell. Going forward, since omega-3 fatty acids are found to have a positive influence on haematopoiesis, it could serve as chemotherapeutic option for people suffering from various blood-related disorders like leukaemia.

\section{Effect of omega-3 fatty acids on body weight}

The increase in obesity patients worldwide has been linked to high intake of foods with high calories that are highly fortified with saturated fatty acids, as well as living a sedentary life styles with little or no physical activity (Shi et al., 2006; Ryeo-Eun et al., 2016; W.H.O. 2016). Research has shown that inclusion of omega-3 fatty acids as feed supplements in the diets of animals and humans supports the reduction of accumulation of fats in the tissues (Hill, Buckley, Murphy, \& Howe, 2007; Rossmeisl et al., 2009, \& Go et al., 2016) whereas some studies totally countered its significant role in influencing lipolysis (Buckley \& Howe, 2009; DeFina et al., 2011; Castilho, Antônio Carlos, \& de Souza, 2015). Omega-3 fatty acids' anti-obesity beneficial effects include enhanced adipocyte apoptosis, improved plasma adiponectin levels, reduced visceral fats deposition, enhanced lipid profile and decreased body fat accumulation, exerting an anti-inflammatory effect in peripheral tissues (Du, Jin, Fang \& Su, 2015; de Mello et al., 2018). In this present study, we observed a slight drop in weight gain of both male and female rats fed with the tested diets of O3FA supplementation when compared with the control, with the change recording no statistical 
significant difference. The observed non-significant effect $(p>0.05)$ in the body weight of treated male and female rats compared with the control in the present study is in consonants with DeFina et al. (2011) and Castilho, Antônio Carlos, \& de Souza (2015) but varies with Go et al. (2016). DeFina et al. (2011) reported no significant weight loss effect in overweight and obese patients with the introduction of omega-3 fatty acid supplementation in conjunction with physical activity. In an attempt to explain the various effects of O3FAs on the body weight as observed in this study, we report that a non-significant increase in body weight could depict that administration of O3FAs initiated an action whereby the anabolic effects synergised with the catabolic one in protecting against excessive body fat deposition. In addition, a meta-analysis performed by Bender et al. (2014) confirmed that the intake of fish oil rich in O3FA produced slight reductions in body weight and waist circumference. In a related study, Du et al. (2015) observed that fish oil had no positive effect on weight loss and body mass index (BMI) in overweight or obese patients. However, there were significant reductions in the waist circumference and hip to waist ratio in obese individuals receiving fish oil supplementation, especially when combined with lifestyle modification intervention. The observed non-significant change but a slight reduction in body weight gains of both male and female albino rats in this present study suggests that omega- 3 fatty acids does not boost adiposity or enhance body fat accumulation but rather modulates fat accumulation in tissues by enhancing adipocyte apoptosis.

\section{Conclusion}

The present study have demonstrated that the use of omega-3 fatty acids as feed supplement poses no adverse health effect on the haematology and body weight of albino Wistar rats (Rattus norvegicus) model, but rather promotes haematopoiesis and aids in attenuation of weight gain. Furthermore, the use of omega-3 fatty acids supplement as a dietary therapy in overweight individuals should be prescribed together with lifestyle modification interventions such as increase in physical exercise and reduction in consumption of food with high calories. Findings from this study will help in elucidating the nutritional importance of omega-3 fatty acids in our diets especially in blood production and weight maintenance. Additionally, why the adult male rats performed best at higher dose $(250 \mathrm{mg} / \mathrm{kg})$ of O3FAs than the adult female rats, which at $150 \mathrm{mg} / \mathrm{kg}$ dose of omega 3 fatty acids performed optimally, remains unknown. We therefore suggest that further studies be conducted using rats of different age brackets with varying doses of omega-3 fatty acids to ascertain the rightful dosage for each age group for optimum body utilisation.

\section{Abbreviations}

O3FAs: Omega-3 fatty acids; PCV: Packed cell volume; Hb: Haemoglobin; WBCs: White blood cells; RBCs: Red blood cells; MCV: Mean cell volume; MCH: Mean cell haemoglobin; MCHC: Mean cell haemoglobin concentration; EDTA: Ethylenediaminetetraacetic acid; ALA: Alpha-linolenic acid; EPA: Eicosapentaenoic acid; DHA: Docosahexanoic acid; ARA: Arachidonic acid

\section{Acknowledgements}

Our sincere appreciation goes to Zoology and Environmental Biology Department, University of Nigeria, Nsukka, for providing the space where the experimental study was performed.

\section{Authors' contributions}

EIN provided all the materials used for this study. EIN, BOM, ECM and GCU designed this research. EIN, CSE and BIE were responsible for the drug administration, feeding and taking care of the experimental animals while BOM supervised these aspects. ECM, EIN and BIE were responsible for the statistical analysis. The first draft of the manuscript was prepared by EIN and edited by BIE. The final version was read and approved by all authors.

\section{Funding}

Mr. and Mrs. Philip Nnamonu financed this study in support of their son's (E.I. Nnamonu) Ph.D. research study.

\section{Availability of data and materials}

All data generated or analysed during this study are included in this manuscript.

\section{Ethics approval and consent to participate}

The ethical conditions and experimental protocol governing the use and conduct of experiments with live animals were strictly observed as approved by the University of Nigeria, Nsukka, Senate Committee on Medical and Research Ethics.

\section{Consent for publication}

Not applicable

Competing interests

The authors declare that they have no competing interests.

\section{Author details}

${ }^{1}$ Federal College of Education, School of Sciences, Department of Biology, School of Sciences, Eha-Amufu, Enugu State, Nigeria. ${ }^{2}$ Faculty of Biological Sciences, Department of Zoology and Environmental Biology, University of Nigeria, Nsukka, Enugu State, Nigeria. ${ }^{3}$ Faculty of Veterinary Medicine, Department of Veterinary Physiology and Pharmacology, University of Nigeria, Nsukka, Enugu State, Nigeria.

Received: 26 July 2019 Accepted: 27 March 2020

Published online: 09 April 2020

\section{References}

Ailhaud, G., Massiera, F., Weill, P., Legrand, P., Alessandri, J. M., \& Guesnet, P. (2006). Temporal changes in dietary fats: role of $n-6$ polyunsaturated fatty acids in excessive adipose tissue development and relationship to obesity. Progress Lipid Research, 45, 203-236.

Al-Attar, A. M., \& Al-Rethea, H. A. (2016). Chemoprotective effect of omega-3 fatty acids on thioacetamide induced hepatic fibrosis in male rats. Saudi Journal of Biological Sciences, 24(4), 956-965.

Al-Daraji, H. J., Al-Hassani, A. S., Al-Mashadani, H., Al-Hayani, W. K., \& Mazi, H. A. (2010). Effect of Dietary Supplimentation with Sources of Omega-3 and Omega-6 fatty acids on certain blood characteristics of laying Quail. International Journal of Poultry Science, 9(7), 689-694.

Anderson, B. M., \& Ma, D. W. (2009). Are all n-3 polyunsaturated fatty acids created equal? Lipids in Health and Disease, 8, 33.

Archibong, A. N., Ofem, O. E., Nna, V. U., Bisong, E. M., Johnson, J. T., \& Eno, A. E. (2014). Changes in haematological parameters following the administration of crude extract from Tympanotonus fuscatus (Periwinkle) in rats. Australian Journal of Basic and Applied Sciences, 8(10), 586-591. 
Ashafa, A. O., Yakubu, M. T., Grierson, D. S., \& Afolayan, A. J. (2009). Effects of aqueous leaf extract from the leaves of Chrysocoma ciliate L. on some biochemical parameters of Wistar rats. African Journal of Biotechnology, 8(8), 1425-1430.

Baker, F. J., Silverton, R. E., \& Pallister, C. J. (2001). Introduction to medical laboratory technology. Ibadan, Nigeria: Bounty Press Limited.

Bender, N., Portmann, M., Heg, Z., Hofmann, K., Zwahlen, M., \& Egger, M. (2014). Fish or n3-PUFA intake and body composition: a systematic review and meta-analysis. Obesity Reviews, 15(8), 657-665.

Birch, E. E., Hoffman, D. R., Castañeda, Y. S., Fawcett, S. L., Birch, D. G., \& Uauy, R. D. (2002). A randomized controlled trial of long-chain polyunsaturated fatty acid supplementation of formula in term infants after weaning at 6 wk of age. American Journal of Clinical Nutrition, 75, 570-580.

Buckley, J. D., \& Howe, P. R. (2009). Anti-obesity effects of long-chain omega-3 polyunsaturated fatty acids. Obesity Reviews, 10, 648-659.

Castilho, T. T., Antônio Carlos, L. C., \& de Souza, L. M. (2015). Effect of omega-3 fatty acid in the healing process of colonic anastomosis in rats. Arquivos Brasileiros De Cirurgia Digestiva, 28(4), 258-261.

De Mello, A. H., Uberti, M. F., de Farias, B. X., de Souza, N. A. R., \& Rezin, G. T. (2018). n-3 PUFA and obesity: from peripheral tissues to the central nervous system. British Journal of Nutrition, 199, 1312-1323.

DeFina, L. F., Marcoux, L. G., Devers, S. M., Cleaver, J. P., \& Willis, B. L. (2011). Effects of omega-3 supplementation in combination with exercise on weight loss and body composition. American Journal of Clinical Nutrition, 93(2), 455-462.

Du, S., Jin, J., Fang, W., \& Su, Q. (2015). Does fish oil have an anti-obesity effect in overweight/ obese adults? A meta-analysis of randomized controlled trials. PLOS ONE, 10(11), e0142652. https://doi.org/10.1371/journal.pone.0142652.

Eno, A. E., Owo, O. I., Itam, E. H., \& Konya, R. S. (2001). Contribution of lymphocyte in edema induced by venom from the wasp (Belonogaster fuscipennis). Pharmaceutical Biology, 39(4), 247-252

Friedman, A., \& Moe, S. (2006). Review of the effects of omega-3 supplementation in dialysis patients. Clinical Journal of the American Society of Nephrology, 1, 182-192.

Gabbs, M., Leng, S., Devassy, J. G., Monirujjaman, M., \& Aukema, H. M. (2015) Advances in our understanding of oxylipins derived from dietary PUFAs. Advances in Nutrition, 5, 513-540.

Go, R.-E., Hwang, K.-A., Park, G.-T., Lee, H.-M., Lee, G.-A., Kim, C.-W., ... Choi, K.-C. (2016). Effects of microalgal polyunsaturated fatty acid oil on body weight and lipid accumulation in the liver of C57BL/ 6 mice fed a high fat diet. The Journal of Biomedical Research, 30(3), 234-242.

Golub, N., Geba, D., Mousa, S. A., Williams, G., \& Block, R. C. (2011). Greasing the wheels of managing overweight and obesity with omega-3 fatty acids. Medical Hypothesis, 77(2011), 1114-1120.

Harris, W. S. (2010). Omega-3 fatty acids. In P. M. Coates, J. M. Betz, M. R. Blackman, G. M. Cragg, M. Levine, J. Moss, \& J. D. White (Eds.), Encyclopedia of dietary supplements, (2nd ed., pp. 577-586). London and New York: Informa Healthcare.

Hassanali, Z., Ametaj, B. N., Field, C. J., Proctor, S. D., \& Vine, D. F. (2010). Dietary supplementation of n-3 PUFA reduces weight gain and improves postprandial lipaemia and the associated inflammatory response in the obese JCR: LA-cp rat. Diabetes, Obesity and Metabolism, 12, 139-147.

Hill, A. M., Buckley, J. D., Murphy, K. J., \& Howe, P. R. (2007). Combining fish-oil supplements with regular aerobic exercise improves body composition and cardiovascular disease risk factors. American Journal of Clinical Nutrition, 85, 1267-1274

Hoff, J. (2010). Methods of blood collection in the mouse. Laboratory Animal, 29(10), 50-51.

Institute of Medicine, Food and Nutrition Board (2005). Dietary reference intakes for energy, carbohydrate, fiber, fat, fatty acids, cholesterol, protein, and amino acids (macronutrients). Washington, DC: National Academy Press.

Kang, J. X. (2003). The importance of omega-6/omega-3 fatty acid ratio in cell function. The gene transfer of omega-3 fatty acid desaturase. In A. P. Simopoulos, \& L. G. Cleland (Eds.), Omega-6/omega-3 essential fatty acid ratio: The scientific evidence, (pp. 23-36). Basel, Switzerland: Karger.

Kelley, D. S. (2001). Modulation of human immune and inflammatory responses by dietary fatty acids. Nutrition Journal, 17(7-8), 669-673.

Kooshki, A., Taleban, F. A., Tabibi, H., \& Hedayati, M. (2011). Effects of omega-3 fatty acids on serum lipids, lipoprotein (a), and hematologic factors in hemodialysis patients. Renal Failure, 33(9), 892-898.

Krebs, J. D., Browning, L. M., McLean, N. K., Rothwell, J. L., Mishra, G. D., Moore, C. S., \& Jebb, S. A. (2006). Additive benefits of long-chain n-3 polyunsaturated fatty acids and weight-loss in the management of cardiovascular disease risk in overweight hyperinsulinaemic women. International Journal of Obesity, 30, $1535-1544$

Majid, T., Mohsen, T., Abas, A. G., \& Sayed, A. T. (2010). Performance, immunity, serum biochemical and haematological parameters in broiler chicks fed dietary thyme as alternative for an antibiotic growth promoter. African Journal of Biotechnology, 9(40), 6819-6825.

Martínez-Fernández, L., Laiglesia, L. M., Huerta, A. E., Martinez, J. A., \& Moreno-Aliaga, M. J. (2015). Omega-3 fatty acids and adipose tissue function in obesity and metabolic syndrome. Prostaglandins \& Other Lipid Mediators, 121, 24-41.

Nagy, K., \& Tiuca, I. (2017). Importance of fatty acids in physiology of human body, fatty acids. IntechOpen. https://doi.org/10.5772/67407.

Ndem, J. I., Akpanabiatu, M. I., \& Essien, E. U. (2008). Effects of sea foods (Periwinkle, Bonkafish and Crayfish) and vegetable oils enriched meal on cardiovascular disease. Pakistan Journal of Nutrition, 7(4), 603-606.

Nuernberg, K., Breier, B. H., Jayasinghe, S. N., Bergmann, H., Thompson, N., Nuernberg, G., ... Huber, K. (2011). Metabolic responses to high-fat diets rich in n-3 or n-6 long-chain polyunsaturated fatty acids in mice selected for either high body weight or leanness explain different health outcomes. Nutrition \& Metabolism, 8(1), 56.

Nwani, C. D., Mkpadobi, B. N., Onyishi, G., Echi, P. C., Chukwuka, C. O., Oluah, S. N., \& Ivoke, N. (2013). Changes in behavior and hematological parameters of freshwater African catfish Clarias gariepinus (Burchell, 1822) following sublethal exposure to chloramphenicol. Drug and Chemical Toxicology, 1-7.

Ochei, J. O., \& Kolhatkar, A. A. (2007). Medical laboratory science: Theory and practice. New Delhi: Tata McGraw-Hill Publishers Company Limited.

Rossmeisl, M., Jelenik, T., Jilkova, Z., Slamova, K., Kus, V., Hensler, M., ... Kopecky, J. (2009). Prevention and reversal of obesity and glucose intolerance in mice by DHA derivatives. Obesity, 17(15), 1023-1031

SanGiovanni, J. P., \& Chew, E. Y. (2005). The role of omega-3 long-chain polyunsaturated fatty acids in health and disease of retina. Progress in Retinal and Eye Research, 24(1), 87-138. https://doi.org/10.1016/j.preteyeres.2004.06.002.

Shi, H., Kokoeva, M. V., Inouye, K., Tzameli, I., Yin, H., \& Flier, J. S. (2006). TLR4 links innate immunity and fatty acids-induced insulin resistance. Journal of Clinical Investigation, 116, 3015-3025. https://doi.org/10.1172/JC128898.

Simopoulos, A. P. (2001). Evolutionary aspects of diet and essential fatty acids. In T. Hamazaki, \& H. Okuyama (Eds.), Fatty acids and lipids-new findings, (pp. 1827). Basel, Switzerland: Karger.

Sood, R. (2006). Medical laboratory technology. New Delhi: Jaypee Brothers Medical Publishers Limited.

Swan, G. (2004). Findings from the latest National Diet and Nutrition Survey. Proceedings of the Nutrition Society, 63, 505-512.

The University of Nigeria, Nsukka, Nigeria Research Policy on Research involving animal subjects (2013). Nigeria: University of Nigeria, Nsukka. p. 25

Thorsdottir, I., Tomasson, H., Gunnarsdottir, I., Gisladottir, E., Kiely, M., Parra, M. D., ... Martinéz, J. A. (2007). Randomized trial of weight-loss-diets for young adults varying in fish and fish oil content. International Journal of Obesity, 31 , 1560-1566.

Troiano, R. P., Briefel, R. R., Carroll, M. D., \& Bialostosky, K. (2000). Energy and fat intakes of children and adolescents in the United States: data from the national health and nutrition examination surveys. American Journal of Clinical Nutrition, 72, 1343S-1353S.

Ukwuani, A. N., Abubakar, M. G., Hassan, S. W., \& Agaie, B. M. (2012). Toxicological studies of hydromethanolic leaves extract of Grewia crenata. International Journal of Pharmaceutical Sciences and Drug Research, 4(4), 245-249.

Varney, M. E., Hardman, W. E., \& Sollars, V. E. (2009). Omega 3 fatty acids reduce myeloid progenitor cell frequency in the bone marrow of mice and promote progenitor cell differentiation. Lipids in Health and Disease, 8(9), 1-6.

Vernaglione, L., Cristofano, C., \& Chimienti, S. (2008). Omega-3 polyunsaturated fatty acids and proxies of cardiovascular disease in hemodialysis: A prospective cohort study. Journal of Nephrology, 21, 99-105.

World Health Organization (2016). Obesity and overweight fact sheet no. 311 http://ww.who.int/mediacentre/factsheets/fs311/en/. Accessed 28 Feb 2020

Yaqoob, P., Pala, H. S., Cortina-Borja, M., Newsholme, E. A., \& Calder, P. C. (2000). Encapsulated fish oil enriched in a-tocopherol alters plasma phospholipid and mononuclear cell fatty acid compositions but not mononuclear cell functions. European Journal of Clinical Investigation, 30, 260.

\section{Publisher's Note}

Springer Nature remains neutral with regard to jurisdictional claims in published maps and institutional affiliations. 